\title{
A Critical Review of the Nigerian Energy Scenario
}

\author{
Diji, C.J \\ Department of Mechanical Engineering University of Ibadan, Ibadan
}

\begin{abstract}
Abundant and economical energy is the life blood of modern civilization. Energy poverty continues to be a major constraint to the developmental and economic of Nigeria and the crucial challenge of the energy sector in the country includes the issues of inadequate energy supply, energy security and sustainability.

This study appraises critically the current energy scenario in Nigeria and examines the roles of all the primary energy forms in the country as well as alternative energy forms in the provision of adequate energy supply and energy security for the future, particularly as it pertains to the attainment of the country's goals for boosting energy supply as articulated in all its policy and developmental documents.

The study identified poor energy mix, slow implementation of policy and inadequate private sector participation as major constraints and challenges of the energy sector and recommends appropriate strategies to improve the energy scenario in the country.
\end{abstract}

Key words: Energy, Sustainability, Nigeria

\section{Introduction}

Abundant and economical energy is the lifeblood of modern civilization. The importance and wide ranging role of energy in the development process of a nation is well known and access to energy is a prerequisite to sustainable development. Energy is central to sustainable development and poverty reduction. It affects all aspects of development - social, economic and environmental - including livelihoods, access to water, agricultural production, education and poverty - related issues.

Nigeria operates a centralized energy system and despite its huge primary energy resources such as oil and gas, abundant sunlight and significant hydropower; energy poverty, the lack of access to reliable, affordable, safe and clean energy resources and services, is a widespread phenomenon amongst its 160 million inhabitants. The crucial challenge of the Nigerian energy sector is the issue of sustainability. This sector is crucial in meeting the nation's developmental goals and should be able to ensure the security and reliability of energy supply and the conversion of its vast energy resources at favourable economical as well as environmentally cost.

This paper presents a critical overview of the current energy scenario in Nigeria in terms of primary energy demand, supply and reserves in Nigeria. The security and sustainability of these primary sources; as well as future energy in various renewable energy options like biomass, wind, solar and hydropower, are also examined. Besides, the paper examines the various energy policies and programmes which are currently being implemented to improve the energy situation in the country.

\section{Energy Mix in Nigeria}

Nigeria is a vast country with a total area of $923,768 \mathrm{sq} \mathrm{km}$, out of which $910,771 \mathrm{sq} \mathrm{km}$ or $98.6 \%$ of total area is land; is Africa's energy giant and is endowed with a variety of fossil and renewable energy types. The Energy Mix in Nigeria is contributed by five main sources, namely oil, natural gas, coal, Biomass and renewable energy. With the advent of democratic governance in 1999, various programmes and plans have been introduced under a broad energy reform programme, with the major objective of encouraging and intensifying the conversion of energy resources and the utilization of renewable energy in the country. Table 1 shows a brief summary of the energy mix in Nigeria.

Table 1: Summary of Nigerian Energy Mix

\begin{tabular}{|c|c|c|c|c|c|}
\hline & \multirow[t]{2}{*}{ Resource Type } & \multicolumn{2}{|c|}{ Reserves } & \multirow[b]{2}{*}{ Production } & \multirow[b]{2}{*}{$\begin{array}{c}\text { Domestic } \\
\text { Utilization } \\
\end{array}$} \\
\hline & & Natural units & $\begin{array}{c}\text { Energy } \\
\text { Units (Btoe) } \\
\end{array}$ & & \\
\hline 1. & Crude Oil & 35 billion barrels & 4.76 & $\begin{array}{ll}2.5 & \text { million } \\
\text { barrels/day }\end{array}$ & $\begin{array}{c}445,000 \\
\text { barrels/day }\end{array}$ \\
\hline 2. & Natural gas & 187 trillion SCF & 4.32 & 7.1 billion SCF/day & $\begin{array}{l}\text { 3.4 billion } \\
\text { SCF/day }\end{array}$ \\
\hline 3. & Coal and Lignite & 2.734 billion tonnes & 1.92 & Insignificant & insignificant \\
\hline 4. & Tar Sands & $\begin{array}{c}31 \text { billion barrels of } \\
\text { equivalent }\end{array}$ & 4.22 & - & - \\
\hline
\end{tabular}




\begin{tabular}{|c|c|c|c|c|c|}
\hline 5. & $\begin{array}{l}\text { Large } \\
\text { Hydropower }\end{array}$ & $11,250 \mathrm{MW}$ & $\begin{array}{l}1.11 \text { (over } \\
38 \mathrm{yrs} \text { ) }\end{array}$ & $\begin{array}{l}1,938 \mathrm{MW} \quad(167.4 \\
\text { million } \mathrm{MWh} / \text { day) }\end{array}$ & $\begin{array}{l}167.4 \text { million } \\
\text { MWh/day }\end{array}$ \\
\hline 6. & $\begin{array}{l}\text { Small } \\
\text { Hydropower }\end{array}$ & 3,500MW & $\begin{array}{c}0.25 \text { (over } \\
38 \mathrm{yrs})\end{array}$ & $\begin{array}{l}\text { 30MW (2.6 million } \\
\text { MWh/day) }\end{array}$ & $\begin{array}{l}2.6 \text { million } \\
\text { MWh/day }\end{array}$ \\
\hline 7. & Solar Radiation & $\begin{array}{l}3.5 \quad- \\
\mathrm{kWh} / \mathrm{m}^{2} / \text { day }(485-1 \\
\text { million MWh/day } \\
\text { using } 0.1 \% \text { of } \\
\text { Nigerian land area) }\end{array}$ & $\begin{array}{c}15.0 \text { (38yrs } \\
\text { and } 0.1 \% \text { of } \\
\text { Nigerian } \\
\text { land) }\end{array}$ & $\begin{array}{ll}\text { Excess of } & 24.0 \mathrm{kwp} \\
\text { of solar PV or } \\
0.001 & \text { million } \\
\text { Mwh/day. } & \end{array}$ & $\begin{array}{c}\text { Excess of } \\
0.01 \text { million } \\
\text { MWph/day of } \\
\text { Solar PV }\end{array}$ \\
\hline 8. & Wind & $\begin{array}{l}2-4 \mathrm{~m} / \mathrm{s} \text { at } 10 \mathrm{~m} \\
\text { height }\end{array}$ & - & - & - \\
\hline \multirow[t]{4}{*}{9.} & \multicolumn{2}{|l|}{ BIOMASS } & & & \\
\hline & Fuelwood & $\begin{array}{l}11 \text { million hectares } \\
\text { of forest and } \\
\text { woodland }\end{array}$ & - & $\begin{array}{l}0.11 \text { million } \\
\text { tonnes/day }\end{array}$ & $\begin{array}{c}0.120 \text { million } \\
\text { tonnes/day }\end{array}$ \\
\hline & Animal waste & $\begin{array}{l}245 \text { million } \\
\text { assorted in } 2001\end{array}$ & - & $\begin{array}{c}0.78 \text { million } \\
\text { tonnes/day in } 2001\end{array}$ & Not Available \\
\hline & $\begin{array}{ll}\text { Energy } & \text { crops } \\
\text { and } & \text { Agric } \\
\text { residues } & \end{array}$ & $\begin{array}{l}72 \text { million hectares } \\
\text { of agric land and } \\
\text { all waste lands }\end{array}$ & - & $\begin{array}{c}\text { Excess of } \\
0.256 \text { million } \\
\text { tonnes of assorted } \\
\text { crops residue/day } \\
\text { in } 1996 \\
\end{array}$ & Not available \\
\hline $\begin{array}{l}1 \\
0\end{array}$ & $\begin{array}{l}\text { Nuclear } \\
\text { Elements }\end{array}$ & Not yet quantified & & & \\
\hline
\end{tabular}

Sources: (i) Nigerian National Petroleum Corporation NNPC, 2007 (ii) Renewable Energy Master Plan (REMP), 2007 (iii) Ministry of Mines and Steel development, 2008

\subsection{Oil}

Crude oil is the singular most important Nigerian energy resources. The export of oil and gas accounts for more than $98 \%$ of export earnings and about $83 \%$ of the Federal Government of Nigeria (FGN) revenue. It also provides more than $40 \%$ of the country's GDP and provides $95 \%$ of foreign exchange earnings and $65 \%$ of governments' budgetary revenues (EIA, 2010).

Oil production started in Nigeria with the discovery of oil in 1956 at Oloibiri in the Niger Delta region of the country. Nigeria joined the ranks of oil producers in 1958 when its first oil field came on stream producing 5,100 barrels per day (bpd). Today with over 159 oil fields and 1,481 wells in operation, the daily production of is estimated at 2.4 million bpd. The country also has a proven oil reserve of 37.2 billion bpd (EIA, 2010).

Nigeria has four existing oil refineries run by the Nigerian National Petroleum Company (NNPC) with a combined capacity of 445,000 barrels per day or the equivalent of 22.2 million metric tonnes per annum (Table 2). However the current operational capacity of the refineries is between 60 and $75 \%$ (EIA, 2011). From Table 2 it can be seen that no new refineries were built in the last 30yrs.

The product slates from the four refineries are white products - Premium Motor Spirit (PMS), Dual Purpose Kerosene (DPK), Automotive Gas Oil (AGO) and liquefied Petroleum Gas (LPG). Other products are Low Pour Fuel Oil (LPFO), High Pour Fuel Oil (HPFO), Bitumen, base oils, Paraffin Wax and sulphur. In addition, the Warri refinery has a petrochemical plant for the production of polypropylene and carbon black, while the Kaduna refinery has a petroleum plant for the production of linear Alkyl Benzene, solvents and Benzene.

Table 2: Refineries in Nigeria

\begin{tabular}{|c|c|c|c|c|c|c|}
\hline & Year & \multicolumn{5}{|c|}{ Capacity (barrels per day) } \\
\cline { 3 - 7 } s/n & Commissioned & $\mathbf{1 9 6 5}$ & $\mathbf{1 9 7 1}$ & $\mathbf{1 9 7 8}$ & $\mathbf{1 9 8 8}$ & $\mathbf{2 0 1 0}$ \\
\hline 1. & Port - Harcourt Refinery I & 35,000 & 60,000 & 60,000 & 60,000 & 60,000 \\
\hline 2. & Port - Harcourt Refinery II & - & - & - & 150,000 & 150,000 \\
\hline 3. & Warri Refinery & - & - & 100,000 & 125.000 & 125,000 \\
\hline 4. & Kaduna Refinery & - & - & 100,000 & 110,000 & 110,000 \\
\hline & Total & $\mathbf{3 5 , 0 0 0}$ & $\mathbf{6 0 , 0 0 0}$ & $\mathbf{2 6 0 , 0 0 0}$ & $\mathbf{4 4 5 , 0 0 0}$ & $\mathbf{4 4 5 , 0 0 0}$ \\
\hline
\end{tabular}

Source: Energy Information Administration (2011)

The inability of the refineries to meet local demand led to the liberalization of the sector and the licensing in 2002 of 18 new private refineries to compliment the operations of the four existing ones and to improve local 
supply of petroleum products. So far of the Eighteen (18) licensed private refineries, thirteen (13) of them have received approval by the FGN to commence construction of private refineries, while only 2 of them so far have commenced construction work.

The two private refineries under construction are the Amakpe Refineries Nigeria Ltd, Eket, Akwa Ibom state with a capacity for 6,000 barrels per day of unleaded gasoline, the construction of the refinery commenced in February 2004; the second refinery is the Orient Petroleum Refinery at Nsugbe - Umuleri, Anambra State which commenced construction work in April 2006, with a capacity of 55,000 barrels per day. The slow completion of the two projects has been due to financial constraints. Also the NNPC has commenced work on the construction of three new green refineries to be located in Lagos, Kogi and Bayelsa States, while the Independent Petroleum Marketers of Nigeria (IPMAN) has commissioned three Chinese firms to build three refineries in Port - Harcourt, Ore and Lokoja.

Petroleum products distribution is managed by the Pipeline and Products Marketing Company (PPMC), a subsidiary of the NNPC. Distribution of products is done via pipelines, Bulk road Vehicles (BRVs) and depots. The PPMC has twenty - three (23) depots, twenty (20) inland and three (3) refinery depots, with storage capacities of $1,070,919 \mathrm{~m}^{3}$ of PMS, $519,000 \mathrm{~m}^{3}$ of DPK, $826,300 \mathrm{~m}^{3}$ of AGO and $75,000 \mathrm{~m}^{3}$ nof ATK (Table 3).

Table 3: National Fuel Products Storage capacity $\left(M^{3}\right)\left(1 M^{3}=1000\right.$ litres $)$

\begin{tabular}{|l|c|c|c|c|}
\hline & PMS & DPK & AGO & ATK \\
\hline Warri Refinery & 99,200 & 87,700 & 97,000 & - \\
\hline Kaduna Refinery & 135,000 & 65,000 & 97,000 & - \\
\hline Port - Harcourt Refinery & 145,550 & 93,000 & 141,000 & - \\
\hline PPMC Depot & 651,000 & 257,000 & 467,000 & 63,500 \\
\hline Marketers @ Apapa & 40,000 & 17,300 & 23,300 & 11,500 \\
\hline \multicolumn{1}{|c|}{ Total } & $1,070,919$ & 519,000 & 826,300 & 75,000 \\
\hline
\end{tabular}

Source: $N N P C$

The depots are connected to the refineries through $5,000 \mathrm{~km}$ of pipelines and seven (7) strategically located booster pump stations. Distribution of petroleum products from depot retail outlets is by BRVs of various capacities. Bridging on pipeline breakdown is done also by using BRVs. There are also nine (9) strategic LPG storage depots located in Lagos, IIorin, Gusau, Kano, Gombe, Markurdi, Enugu, Calabar and Kaduna. There are also ninety (90) LPG filling stations in Nigeria.

The Nigerian oil industry has been responsible for damaging the environment in the Niger Delta region through construction work, dredging, oil spills, leakages and gas flaring. Moreover, despite significant social investment in the Niger Delta region, the industry has not stimulated improvements to the general socioeconomic situation in the region or the country as a whole - including Nigeria's energy crisis. Continuing allegations are aimed towards the government regarding corruption and misuse of revenues and other associated financial flows.

Locally, International Oil Companies (IOCs) are widely perceived as being unaware of the implications of their activities on the ground. This includes environmental damage and its impact on livelihoods; inherent problems with community relationship-building processes; and the tendency to devise development programmes without due consultation. Development initiatives have failed to be sustainable and have resulted in a dependency culture and a subgroup of benefit captors (who engage in patronage networks, criminal activities and political corruption) within the Niger Delta.

The perceived failure of the industry to improve local living conditions has exacerbated unrest in the Delta and the conflict has caused considerable reputational damage to IOCs, and has had a negative impact on the investment climate in the country. As a result, IOCs are actively seeking ways to address development issues in the Delta to improve relations with local communities and the government, and improve international perceptions of oil and gas development in Nigeria. There is a sense of urgency and considerable amounts of money are being directed to the region. Yet there is also a sense that IOCs and other players are unsure where they should focus their efforts in order to be most effective.

Also, the activities of the IOCs and the perceived incompetence of the industry watchdog the NNPC have resulted severally in the calls for general reforms in the sector. The reform instrument in the sector has been the proposed Petroleum industry Bill (PIB). The PIB is expected to reform the structure, governance and fiscal rules of the country's oil industry, which is beset by years of corruption and inefficiency. The PIB amongst other things is expected to restructure the upstream and downstream sector of the oil industry and transform the oil industry into an engine of sustainable development, enhance governance and eliminate toxic social and environmental impacts on producing communities.

There are several "versions" of the PIB in circulation, but the FGN has promised to send the official version of the bill to the national assembly for legislation and passing into law as soon as possible. 


\subsection{Natural Gas}

Nigeria has an estimated 187 Trillion Cubic Feet (TCF) of proven natural gas reserves, making it the seventh largest in the world. Nigeria's natural gas is a high grade gas with $0 \%$ sulphur and rich in high grade gas liquids. The vast majority of natural gas found in Nigeria is associated meaning that it occurs in crude oil reserve as free gas. Because many of the oil fields in the country lack the infrastructure to produce the associated natural gas, it is flared. Nigeria flares more natural gas than any country in the world, with $43 \%$ of its total annual natural gas production being flared (EIA, 2010).

Nigeria's natural gas resources are under-utilized domestically and most gas is exported.

According to the US Energy Information Administration, in 2004, Nigeria produced 800 billion cubic feet, consumed 325 billion cubic feet, and exported 475 cubic feet.26 In 2008, Reuters reported that Nigeria was exporting about 3 billion cubic feet of gas per day (in the form of LNG), while flaring approximately 2.5 billion cubic feet per day, and delivering only 0.5 billion cubic feet per day to the domestic power sector (Shaad and Wilson, 2009).With so much gas being flared, Nigeria is missing out on significant revenue, while valuable resources are being wasted that could be used by communities for power generation and other needs if the appropriate infrastructure were in place.

Nigeria is the second largest gas flarer behind Russia. Gas flaring was officially banned in

Nigeria in 1984 and a groundbreaking court case ruled against flaring in November 2005.

Although IOCs have made efforts in the last 10 years to reduce gas flaring, it has been

Impossible to achieve a total "flares out" because of the lack of domestic gas pricing in Nigeria and the technological and political challenges of gas capture and transportation in isolated areas. Under the gas flaring policy that took effect from 1 January 2008, companies pay a fine of $\$ 3.5$ for every 1000 standard cub feet of gas flared. They were also required to shut down any oil field where associated gas is flared after 31 December 2008. However, it proved impossible to ensure full compliance and the deadline for 'flares out' was shifted to 31 December 2011.

For the effective utilization of gas and reduction in the incidence of gas flaring in the oil producing areas of the country, the Federal Executive Council in February 2008 approved a Gas Master plan for the Nation. The Gas Master Plan is expected to make Nigeria a global player in the international gas market and lay a solid foundation and framework for gas infrastructure expansion within the domestic market. The Gas MasterPlan is a guide for the commercial exploitation and management of Nigeria's gas sector. It aims at growing the Nigerian economy with gas by pursuing three key strategies: Stimulate the multiplier effect of gas in the domestic economy; Position Nigeria competitively in high value export markets and Guarantee the long term energy security of Nigeria.

The Nigerian Gas Master-plan is the first major attempt by the country to articulate a holistic framework for its gas. It comprises three key sections: Gas Pricing Policy; Gas Supply Obligation Regulation and a Gas Infrastructure Blueprint. The objective of the gas pricing policy is to create a structured and transparent framework for gas pricing that supports the government's aspiration for accelerated domestic economic growth via rapid gas based industrialization and maximizing value from high value LNG and pipeline exports. The policy establishes three broad categories for buyers of gas in view of the unique strategic and market dynamics of the various demand sectors: Strategic Domestic sector- primarily the power sector (grid power); Strategic Industrial Sector - Sectors that take gas as main feedstock i.e. gas based industries such as fertilizer, Methanol, GTL, LNG etc; Commercial Sector - Sectors that take gas for fuel. The policy does not fix gas prices, but provides a framework for establishing the minimum gas price that can be charged to any category of gas buyer.

The objective of the domestic gas supply obligation framework is to ensure gas availability for critical domestic gas utilization projects which will advance the domestic economic growth agenda; while the gas infrastructure blueprint is expected to guide all future gas infrastructure developments in the country and is intended to be private sector led and commercially driven. Specifically, the blueprint provides for the establishment of three gas gathering and processing facilities which is a network of gas transmission lines. This infrastructure will result in a reduced cost of gas supply from Nigeria and expedite the Nation's aspiration of gaining market share in the high value export market.

The infrastructure for exploitation of the Nigerian natural gas is managed by the Nigerian Gas company (NGC), a subsidiary of NNPC. The company owns approximately $1,100 \mathrm{~km}$ of various diameters of gas pipelines located East and West of the Southern part of River Niger, with a northern extension to Ajaokuta. The system is capable of transmitting about 1,800MSCf/day of gas (ige, 2010). The Nigerian Liquefied Natural Gas (NLNG) company in Bonny, Rivers state is responsible for the liquefaction and export of liquid natural gas for the country. It is a limited liability company owned by NNPC (49\%), Shell (25.6\%), ELF (16\%) and AGIP (10.4\%) as shareholders (Energy digest, 1999).

The NLNG currently has six trains facility for liquefaction and export of liquid natural gas with capacity of 22 million tonnes per annum (MTPA) of LNG. The seventh train is under construction, while the 
OK, Brass and other third party facilities are currently under evaluation (Ige, 2010). Currently Nigeria has now the second fastest growing LNG capacity after Qatar. At the regional level, the West African Gas Pipeline Project (WAGPP), has been put in place for the export of natural gas across West Africa and has a capacity of 20 million SCF/day. The pipeline originates from the Lagos end of the ESCAVOS Lagos gas pipeline and terminates in Accra, Ghana. There is also continued progress on the Trans - Sahara Gas project which is expected to supply gas to Europe through Algeria and the Equatorial Guinea Gas supply project (Ige, 2010).

With the new Gas Master Plan, three (3) central gas gathering and processing facilities CPFs are under construction and located in Western Delta (Warri/Forcados area); Obiafu (North Port - Harcourt) and Akwa ibom/Calabar Area. Also three (3) gas transmission systems that will link the existing gas transmission lines are under construction. They are : $120 \mathrm{Km}$ South - North line; $700 \mathrm{Km}$ Western System with $200 \mathrm{Km}$ offshore extension and a $200 \mathrm{Km}$ interconnection system to link the old and new systems to give the country a gas supply grid.

\subsection{Coal}

Coal is the oldest commercial fuel, and was discovered in Nigeria in 1909 and its subsequent mining began at Ogbutte in Enugu in 1916 with a total production of 24,000 tons. Coal Production peaked at near one million tons in 1959, before declining to the present insignificant level. Between 1950 and 1959, coal contributed over $70 \%$ of the total commercial energy consumed in Nigeria but today its contribution is $0 \%$. This situation arose due to the reduction in the demand for coal arising from dieselization of rail transportation, and switching from coal to gas for thermal power generation. For example of the licenses granted by NERC (National Electricity Regulatory Commission) so far to Independent Power Producers (IPPs) are all for gas powered plants and only one for coal - fired.

Nevertheless, Nigeria's coal reserves are large, over 2 billion metric tonnes, of which 650 million tonnes are proven. Coal production is from the Cretaceous Anambra Basin which extends to Dekina in the northern part of the basin in Benue State and to Okigwe in the south. The coal in this basin is sub- bituminous and occurs principally at two levels, the lower coal measures (Mamu Formation) and the upper coal measures (Nsukka Formation). Currently coal is found in 14 out of the 36 states in Nigeria, there are coal reserves in Enugu, Imo, Kogi, Delta, Plateau, Anambra, Abia, Benue, Edo, Bauchi, Adamawa, Gombe, Cross - river and Ebonyi states (Dolbear, 2005)

There are two major types of coal namely anthracite and bituminous. A little below bituminous in quality is sub-bituminous which is the major type found in Nigeria. It is important as fuel because it burns slowly and gives out a lot of heat. Nigerian sub bituminous coal has a high calorific value $(5,000-6,000 \mathrm{cal} / \mathrm{g}$ or 5500-6500 air dried), low ash and low sulfur contents, with good storage characteristics (Onlinenigeria, 2009). Nigerian sub - bituminous coal will be very attractive for export, because of its low sulfur content which is environmentally acceptable.

Nigeria also has the largest lignite deposit in Africa, with reserves of about 50 million tonnes. The Nigerian lignite belt, of mid-Tertiary age, extends from Orlu in the south-east, through Urnuezeala, Umuahia, Nnewi, Oba, in a 20 to 40km - wide belt across the Niger, to Ogwashi, Asaba, Mgbiigliba and Adiase-Uti in Delta State. It has not yet been exploited.

The Nigerian Coal Corporation (NCC) was established in 1950 under the Coal Ordinance No. 20. NCC had the exclusive rights to mine Coal in Nigerian until 1999, when the FGN established a policy and legislation that de-regulated mineral exploration and exploration. This opened up the sector to private industry participation and resulted in NCC entering into joint ventures on an equity participation basis. The Agency has recently entered into several joint ventures with outside entities to mine coal, but those efforts have met with limited success. Nigeria's only significant coal mine is the Okaba mine (Okaba coal field), which is operated under a production sharing agreement with Nordic Industries Limited. Production of 2,712 tonnes was recorded in 2001. The NCC is currently divesting from all its operations in the sector.

The NCC has over twenty one (21) Coal Blocks located across the Country which are wholly owned and developed by the Corporation. However, ten (10) of such Coal Blocks are being prepared for privatization. They are: Okpara Mine (Enugu State); Onyeama Mine (Enugu State); Okaba Coal Field (Kogi State); Owukpa Coal Field (Benue State); Ogboyoga I Coal Field (Kogi State); Ogboyoga II Coal Field (Kogi State); Ezinmo Coal Field (Enugu State); Inyi Coal Field (Enugu State); Ogwashi-Azagba Lignite Field (Delta State); and Amansiodo Coal Field (Enugu State).

Nigeria has major coal resources that have not been well explored or exploited, if fully revitalized, the coal industry could fetch up to 5 billion Naira in export earnings. The FGN under the Electric Power Sector Reform Act (EPRSA) and the vision 20:2020 has placed a high priority on utilizing those resources to increase the country's electrical generating capacity. Nigeria's goal is to revitalize the coal mining industry and expand power generation by attracting foreign companies to develop these large coal resources and construct coal-fired generating plants that will connect to the country's electrical distribution grid. 
There is also a significant potential domestic demand for coal briquettes to replace wood for cooking and domestic and industrial heating. The use of wood by the country's growing population is causing increasingly rapid deforestation in many parts of the country. The exploitation of coal for electricity generation and the production of coal briquettes for domestic and industrial heating will bring a number of benefits including: Increased and more reliable electricity supply; Lower cost electrical energy; Expanded industrialization of the economy; Increased employment and human resources development; Increased capacity utilization of existing industries; Increased national income through taxes and Reduced deforestation and prevention of desert encroachment in the northern parts of the country.

\subsection{Electricity}

The provision of adequate electricity supply is the major energy constraint in Nigeria. About 60 per cent of Nigeria's population has no access to electricity ( 90 per cent in rural areas). People need power for lighting (e.g. for evening study); household appliances; irrigation pumps; health clinics (e.g. vaccine refrigeration); food and agricultural processing (e.g. cassava driers and rice mills); and transport fuel. Smallscale traders, manufacturers and craftspeople also require power for small-scale machinery, such as sewing machines. Lighting is the most expensive energy need. The poorest African households may spend 10-15 per cent of their income on kerosene lamps or candles. Nigeria's poorest households earn 1-2 USD per day, but they spend on average 0.40 USD per day on their energy needs (Hammond et al. 2007).

\section{Electricity Generation}

Currently, the Nigerian electricity power generation sector can be sub - divided into three sub sectors, namely: Existing FGN power generation facilities, Independent Power Projects (IPPs) and National Integrated Power Projects (NIPPs). The total installed generating capacity of the FGN power generating units are a total of $1,900 \mathrm{MW}$ of hydro and 5,004.6MW; however the available capacity for the hydro plants is $1,380 \mathrm{MW}$ and $1,978 \mathrm{MW}$ of thermal power.

The IPPs, which are all thermal plants, are the non - FGN funded investment in the Nigerian power sector and their current installed and available capacities are respectively 1,759MW and 1,484MW. The NIPPs, which are also thermal plants are power projects funded by the three tiers of government in Nigeria (Federal, State and Local government). These facilities are currently being constructed and the total designed generating capacity of the NIPPs is currently 4,775MW (BPE, 2010). Thus currently the total installed generating capacity of the power sector in Nigeria is about $8,663 \mathrm{MW}$ (excluding about 4,775MW under construction), as at December 2010 (Onaguruwa, 2011) as shown in Table 4 and 5; however available capacity is about 4,842MW. Figure 1 shows the installed and available generating power in the country, while Table 6 shows the NIPP power plants under construction in various parts of the country.

Table 4: Existing Government Owned Thermal and Hydro Power Plants

\begin{tabular}{|c|c|c|c|c|c|c|}
\hline $\mathbf{s} / \mathbf{n}$ & $\begin{array}{l}\text { Name of } \\
\text { Generation } \\
\text { Company }\end{array}$ & $\begin{array}{c}\text { Year } \\
\text { of } \\
\text { Const }\end{array}$ & Type & Location & $\begin{array}{l}\text { Installed } \\
\text { Capacity } \\
\text { (MW) }\end{array}$ & $\begin{array}{c}\text { Available } \\
\text { Capacity } \\
\text { (MW) }\end{array}$ \\
\hline 1 & Egbin Power PLC & 1986 & Thermal & Egbin, Lagos State & 1320 & 1100 \\
\hline 2 & Geregu Power PLC & 2007 & Thermal & Geregu, Kogi State & 414 & 276 \\
\hline 3 & Omotosho Power PLC & 2007 & Thermal & Omotosho, Ondo State & 304 & 76 \\
\hline 4 & Olorunsogo Power PLC & 2008 & Thermal & Olorunsogo, Ogun State & 304 & 76 \\
\hline 5 & Delta Power PLC & 1966 & Thermal & Ughelli, Delta State & 900 & 300 \\
\hline 6 & Sapele Power PLC & 1978 & Thermal & Sapele, Delta State & 1020 & 90 \\
\hline 7 & $\begin{array}{l}\text { Afam (IV - V) Power } \\
\text { PLC }\end{array}$ & $\begin{array}{c}1963 / 0 \\
1\end{array}$ & Thermal & Afam, Rivers State & 726 & 60 \\
\hline 8 & $\begin{array}{lll}\text { Calabar } & \text { Thermal Power } \\
\text { Station } & & \\
\end{array}$ & 1934 & Thermal & $\begin{array}{l}\text { Calabar, Cross - River } \\
\text { state }\end{array}$ & 6.6 & Nil \\
\hline 9 & Oji River Power Station & 1956 & Thermal & $\begin{array}{ll}\text { Oji } & \text { River, Anambra } \\
\text { State } & \end{array}$ & 10 & nil \\
\hline 10 & $\begin{array}{l}\text { Kainji/Jebba Hydroelectric } \\
\text { PLC - Kanji Power } \\
\text { Station }\end{array}$ & 1968 & Hydro & Kainji, Niger State & 760 & 480 \\
\hline 11 & $\begin{array}{l}\text { Kainji/Jebba Hydroelectric } \\
\text { PLC - Jebba Power } \\
\text { Station }\end{array}$ & 1985 & Hydro & Jebba, Niger State & 540 & 450 \\
\hline 12 & Shiroro Hydroelectric PLC & 1989 & Hydro & Shiroro, Niger State & 600 & 450 \\
\hline & \multicolumn{4}{|c|}{ TOTAL } & 6904.6 & 3,358 \\
\hline
\end{tabular}

Source: Nigerian Bureau of Public Enterprises (BPE, 2011) 
Table 5: Existing Independent Power Projects in Nigeria

\begin{tabular}{|l|l|l|l|c|c|}
\hline s/n & $\begin{array}{l}\text { Name of } \\
\text { Generation Company }\end{array}$ & Type & Location & $\begin{array}{c}\text { Installed } \\
\text { Capacity } \\
\text { (MW) }\end{array}$ & $\begin{array}{c}\text { Available } \\
\text { Capacity } \\
\text { (MW) }\end{array}$ \\
\hline 1 & AES Power Station & Thermal & Egbin, Lagos State & 224 & 224 \\
\hline 2 & Shell Afam IV Power Station & Thermal & Afam, Rivers State & 650 & 650 \\
\hline 3 & Agip Okpai Power Station & Thermal & Okpai, Delta State & 480 & 480 \\
\hline 4 & ASG Ibom Power Station & Thermal & Akwa Ibom State & 155 & 76 \\
\hline 5 & $\begin{array}{l}\text { RSG Trans Amadi Power } \\
\text { Station }\end{array}$ & Thermal & $\begin{array}{l}\text { Port Harcourt, Rivers } \\
\text { State }\end{array}$ & 100 & 24 \\
\hline 6 & RSG Omoku Power Station & Thermal & Omoku, Rivers State & 1150 & 30 \\
\hline & TOTAL & $\mathbf{1 , 7 5 9}$ & $\mathbf{1 , 4 8 4}$ \\
\hline
\end{tabular}

Source: BPE, 2011

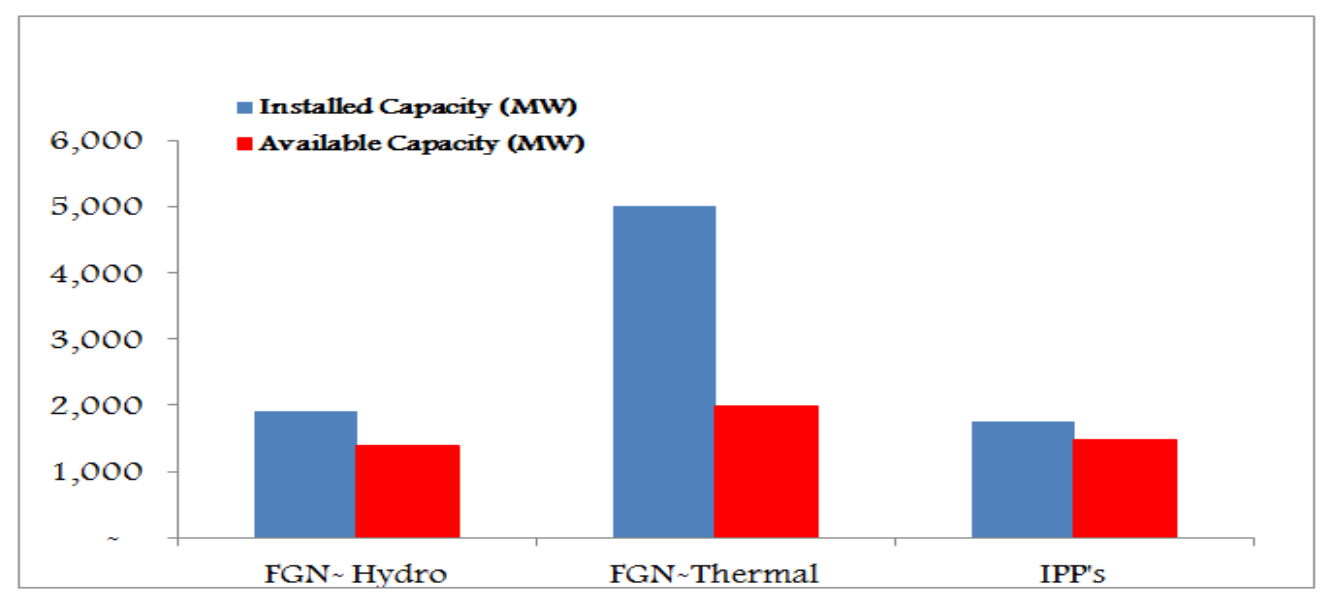

Figure 1: Installed and Available Power in the Nigerian Power Sector.

Table 6: NIPP Power Plants

\begin{tabular}{|l|l|l|c|}
\hline $\begin{array}{l}\text { S/ } \\
\text { N }\end{array}$ & \multicolumn{1}{|c|}{ Name Of Power Plant } & \multicolumn{1}{|c|}{ Location } & $\begin{array}{c}\text { Designed Capacity } \\
\text { (MW) }\end{array}$ \\
\hline 1. & Calabar Power Project & Calabar, Cross river State & 563 \\
\hline 2. & Egbema Power Project & Egbema, Imo State & 338 \\
\hline 3. & Ihovbor Power Project & Ihovbor, Edo State & 451 \\
\hline 4. & Gbaran Power Project & Gbaran, Bayelsa State & 225 \\
\hline 5. & Sapele Power Project & Sapele, Delta State & 451 \\
\hline 6. & Omoku Power Project & Omoku, Rivers State & 225 \\
\hline 7. & Alaoji Power Project & Alaoji, Abia State & 961 \\
\hline 8. & Olorunsogo - Phase2 - Project & Olorunsogo - Ogun State & 676 \\
\hline 9. & Omotosho - Phase2 - Project & 451 \\
\hline 10. & Geregu Phase2 - Project & Omotosho, Ondo State & 434 \\
\hline & \multicolumn{2}{|l|}{ TOTAL } & $\mathbf{4 , 7 7 5}$ \\
\hline
\end{tabular}

Source: BPE, 2011

\section{Electricity Transmission}

The National grid; the network of transmission lines that transverse the country is now owned and managed by the Transmission Company of Nigeria $(\mathrm{TCN})$. The TCN was created as a result of the unbundling of NEPA in 2005. It is owned by the FGN and has responsibility of undertaking the system operation and market settlement functions. The TCN is currently divided into two departments namely: the Transmission Service Provider (TSP) and the System Operator (SO).

The TSP develops the transmission grid to new areas and maintains the infrastructure in the Grid while the SO operates the whole system which includes the Generation Companies (GENCOs) and the Distribution Companies (DISCOs). It does this by deciding which power station comes on and when and by how many Megawatts (MW) and decides which transmission line or transmission station should be supplied what quantity of MW i.e. load shedding. The SO also enforces grid discipline. The TCN operations cover the 36 states of Nigeria and administratively it is divided into 8 transmission regions and 35 work centers. 
As shown in Table 7, there has been an impressive increase in the number of transmission lines between 1973 to date. The current average available transmission capacity on the 330/132 KV and 132/33KV transformers are respectively 7,364MVA and 8,448MVA, representing $95.8 \%$ and $94.1 \%$ of installed capacity respectively. Also the current average transmission loss is $8.5 \%$ (Labo, 2010).

There are also various on-going transmission projects as shown in Table 18 which are financed both by the Federal Government of Nigeria and the NIPPs, with the objective of improving the transmission capacity of the Nigerian power sector. The total transformation capacity of the transmission network as shown in Table 7 currently stands at a capacity of 16,818 MVA (14,295.3MW) (Akarakiri, 1999\& Labo, 2010). Table 8 shows the on - going transmission projects in the country.

Table 7: Nigerian Transmission Infrastructure (1973 - 2010)

\begin{tabular}{|l|c|c|c|c|c|}
\hline Description & $\mathbf{1 9 7 3}$ & $\mathbf{1 9 9 6}$ & $\mathbf{1 9 9 9}$ & $\mathbf{2 0 1 0}$ & $\begin{array}{c}\text { Current Transformation } \\
\text { Capacity MVA(MW) }\end{array}$ \\
\hline 330 KV Transmission lines (Km) & 1262 & 5000 & 4889.2 & 5523.8 & - \\
\hline 132 KV Transmission lines (Km) & 1012 & 6000 & 6319.33 & 6801.49 & - \\
\hline 330/132 KV Substations & 6 & 23 & 21 & 32 & $7,688(6,534.8)$ \\
\hline 132/33 /11KV Substation & 14 & 91 & 99 & 108 & $9,130(7,760.5)$ \\
\hline
\end{tabular}

Source: Akarakiri (1999) \& Labo (2010)

Table 8: On - going Nigerian Power Transmission Infrastructural Projects

\begin{tabular}{|c|c|c|}
\hline Project & FGN & NIPP \\
\hline $330 \mathrm{KV}$ Transmission lines $(\mathrm{Km})$ & 986.5 & 2194 \\
\hline 132 KV Transmission lines (km) & 705.3 & 809 \\
\hline $\begin{array}{l}\text { 330/132 KV Transformer capacity } \\
\text { (MVA) }\end{array}$ & 1350 & 5590 \\
\hline $\begin{array}{l}\text { 132/33 KV Transformer capacity } \\
\text { (MVA) }\end{array}$ & 3000 & 3313 \\
\hline \multirow[t]{2}{*}{ Others } & $\begin{array}{l}\text { Reinforcement of Overloaded } \\
\text { transmission stations with } \\
\text { additional capacity. }\end{array}$ & $\begin{array}{lcccc}\text { Installation } & \text { of } & 10 & \text { new } & 330 \mathrm{KV} \\
\text { substation } & \text { and } & 7 & \text { new } & 132 \mathrm{KV} \\
\text { substation. } & & & & \\
\end{array}$ \\
\hline & $\begin{array}{l}\text { Overloaded transmission lines are } \\
\text { being re }- \text { conductor with high } \\
\text { capacity conductors. }\end{array}$ & $\begin{array}{l}\text { Expansion and reinforcement of } 32 \\
\text { existing } 330 \mathrm{KV} \text { and } 132 \mathrm{KV} \\
\text { substations }\end{array}$ \\
\hline
\end{tabular}

Source: Labo (2010)

\section{Electricity Distribution}

Electricity distribution in Nigeria is currently done through the Distribution Companies (DISCOs) which perform the functions of distributing electricity in apportion authorized areas on $240 \mathrm{~V}$ up to $33 \mathrm{KV}$ networks of the Nigerian electricity Industry. In addition, Discos are expected to have the responsibility of overseeing retail operations to end users of electricity. Currently the Nigerian power sector has 11 Discos and span across the country.

The trend in the increase of distributive capacity of the companies since 1999 is shown in Table 9, while the current distributive capacity is stated as (FGN, 2010): 50,179km of total installed 33KKVA line; $34,868 \mathrm{~km}$ of total installed 11KVA line; 10,506 MVA - total installed injector substation capacity; 17,899 MVA - total installed distributive substation capacity; 1,078 No. of 33/11KV transformers and 41,477 No. of $33 / 0.415 / 11 \mathrm{KV}$ transformers. In order to improve the distributive capacity of the power sector, the FGN invested $\$ 0.5225$ billion (N81billion) in various distributive projects in the country. These projects are on going and consist of $1,707 \mathrm{~km}$ of new $33 \mathrm{KV}$ lines, $2,666 \mathrm{Km}$ of new $11 \mathrm{KV}$ lines, additional $3540 \mathrm{MVA}$ sub station capacity and 22, 598 transformers (Labo, 2010).

Table 9: The Distribution Network of the Nigerian Power Sector

\begin{tabular}{|l|l|l|l|l|}
\hline S/N & \multicolumn{1}{|c|}{ Distribution Network } & \multicolumn{1}{|c|}{$\mathbf{1 9 9 9}$} & \multicolumn{1}{|c|}{$\mathbf{2 0 0 8}$} & \multicolumn{1}{|c|}{$\mathbf{2 0 1 0}$} \\
\hline 1. & 33KV lines $(\mathrm{km})$ & 37,173 & $48,409.62$ & 50,179 \\
\hline 2. & 11KV lines $(\mathrm{km})$ & 29,055 & $32,581.49$ & 34,868 \\
\hline 3. & 415V $(\mathrm{km})$ & 70,799 & $126,032.79$ & 193,822 \\
\hline 4. & Transforming Capacity (MVA) & $8,342.56$ & 12,219 & 17,899 \\
\hline
\end{tabular}

Source: Maigada (2008)

The electricity sector in Nigeria is currently under reforms. The reform was initiated with the approval by the FGN in March 2001 of the National Electric Power Policy (NEPP). The key policy objectives of the NEPP include in the short term to ensure a system of generation, transmission, distribution and marketing that is 
efficient, safe, affordable and cost - effective throughout the country; ensure that the power sector attracts private investment both from within and outside the country and promote competition to meet growing demands through the full liberalization of the electricity market. (El - Rufai, 2001).

The major fall out of the policy was the vertically unbundling of NEPA - National Electric Power Authority into generation, transmission and distribution in 2004 and the passage into law of the Electric Power Sector Reform Act (EPSRA) in March 2005. The EPSRA became the legal and regulatory framework for driving the power sector reforms. The EPSRA set in motion the necessary legal framework for the unbundling of NEPA into 18 autonomous companies - 11 distribution companies, one generation company, and one transmission company; the establishment of the Nigerian Electricity Regulatory Commission (NERC) and the creation of the Power Holding Company of Nigeria (PHCN) which came into effect in June 2005.

NERC was established as an independent regulator to drive the power sector reform through: Creating and preserving efficient market structures; Maximizing access across Nigeria to distribution networks; Ensuring safe, secure, reliable qualitative and adequate production and supply of electricity to all consumers; Ensuring regulation is fair and balanced for licensees, consumers, investors and other stakeholders; and Ensuring fair tariffs to consumers, sufficient to allow reasonable earnings for efficient operations and financing operations. The NERC in 2008 prepared and got approval for market rules to guide the operations in the electricity industry and also issued the relevant market code (Grid, Distribution, Performance and metering etc) to guide the electricity industry.

In pursuance of its powers, the NERC on July 1, 2008 established a 15 years tariff path for the Nigerian Electricity Industry, the Multi - Year - Tariff - Order (MYTO) for the determination of charges and tariffs for electricity generation, transmission and retail tariffs over the period of July $1^{\text {st }}, 2008$ to June $30^{\text {th }} 2013$. Also in February 2009, the agency licensed a total of 28 firms as Independent Power Producers (IPP) to compliment government efforts at providing sufficient power to meet domestic needs, (Table 10).

\subsection{Biomass}

Biomass is defined as organic material, available on renewable basis, which are produced directly or indirectly from living organisms without contamination from other substances or effluents. Biomass includes forest and mill residue, agricultural crops and wastes, wood and wood wastes, animal waste, livestock operation residues, aquatic plants, fast growing trees and plants, municipal and industrial waste. The various types of plant biomass are shown in Table 4.

Table 10: Independent Power Producers (IPPs) Licensed by NERC by 20/02/09

\begin{tabular}{|c|c|c|c|c|c|c|}
\hline $\begin{array}{l}\mathbf{S} / \\
\mathbf{N}\end{array}$ & Name of Applicant & Type of License & $\begin{array}{l}\text { Total } \\
\text { capacity }\end{array}$ & $\begin{array}{l}\text { Fuel } \\
\text { Type }\end{array}$ & $\begin{array}{l}\text { Site } \\
\text { Location }\end{array}$ & State \\
\hline 1. & Ethiope Energy Ltd & Generation on Grid & 2800MW & Gas & Ogorode & Delta \\
\hline 2. & Farm Electric Supply Ltd & “ & $150 \mathrm{MW}$ & Gas & Ota & Ogun \\
\hline 3. & ICS Power Ltd & “" & 624MW & Gas & Alaoji & Abia \\
\hline 4. & Supertick Nig. Ltd & “" & 1000MW & Gas & Akwete & Abia \\
\hline 5. & Mabon Ltd & “" & 39MW & Hydro & Dadinkowa & Gombe \\
\hline 6. & Geometric Power Ltd & “ & 140MW & Gas & Aba & Abia \\
\hline 7. & Aba Power Ltd & Distribution & - & - & Aba & Abia \\
\hline 8. & $\begin{array}{l}\text { Weatern Technologies \& } \\
\text { Energy Services Ltd }\end{array}$ & Generation on grid & $1000 \mathrm{MW}$ & Gas & Sagamu & Ogun \\
\hline 9. & Lotus \& Bresson Nig. Ltd & “ & $60 \mathrm{MW}$ & Gas & Magboro & Ogun \\
\hline 10. & Anita Energy Ltd & “" & $90 \mathrm{MW}$ & Gas & Agbara & Lagos \\
\hline 11. & $\begin{array}{l}\text { First Independent Power } \\
\text { Co. Ltd }\end{array}$ & “ & $150 \mathrm{MW}$ & Gas & Omoku & Rivers \\
\hline 12. & $\begin{array}{l}\text { First Independent Power } \\
\text { Co. Ltd }\end{array}$ & “" & $136 \mathrm{MW}$ & Gas & $\begin{array}{l}\text { Trams } \\
\text { Amadi }\end{array}$ & Rivers \\
\hline 13. & $\begin{array}{l}\text { First Independent Power } \\
\text { Co. Ltd }\end{array}$ & “" & $95 \mathrm{MW}$ & Gas & Eleme & Rivers \\
\hline 14. & Hudson power Station Ltd & “" & $150 \mathrm{MW}$ & Gas & Warewa & Ogun \\
\hline 15. & Ibafo Power Station Ltd & “ & 200MW & Gas & Ibafo & Ogun \\
\hline 16. & Shell Distribution Co. Ltd & “" & 640MW & Gas & Afam & Rivers \\
\hline 17. & $\begin{array}{lll}\text { Agbara Shoreline Power } \\
\text { Co. Ltd }\end{array}$ & “ & 100MW & Gas & Agbara & Lagos \\
\hline 18. & Nigeria Agip Oil Co. Ltd & “ & 480MW & Gas & Okpai & Delta \\
\hline 19. & 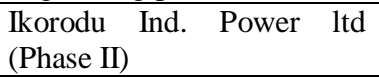 & “" & 140MW & Gas & Ikorodu & Lagos \\
\hline 20. & Ming Holdings Ltd & " & $115 \mathrm{MW}$ & Coal & Enugu & Enugu \\
\hline 21. & Ibom Power Ltd & “" & 190MW & Gas & Ikot Abasi & Akwa \\
\hline
\end{tabular}


A Critical Review of the Nigerian Energy Scenario

\begin{tabular}{|l|l|l|c|c|l|l|}
\hline & & & & & & Ibom \\
\hline 22. & Notore Power ltd & \multicolumn{1}{|c|}{ " } & $50 \mathrm{MW}$ & Gas & Onne & Rivers \\
\hline 23 & Ewekoro Power Ltd & Generation off grid & $13 \mathrm{MW}$ & Gas & Ewekoro & Ogun \\
\hline 24. & $\begin{array}{l}\text { Ikorodu Industrial. Power } \\
\text { Ltd }\end{array}$ & Distribution & - & - & Ikorodu & Lagos \\
\hline 25. & CET Power Projects Ltd & Generation off grid & $20 \mathrm{MW}$ & Gas & Tinapa & $\begin{array}{l}\text { Cross } \\
\text { Rivers }\end{array}$ \\
\hline 26 & $\begin{array}{l}\text { Ikorodu Industrial Power } \\
\text { Ltd }\end{array}$ & Embedded Generation & $39 \mathrm{MW}$ & Gas & Ikorodu & Lagos \\
\hline 27. & CET Power Projects Ltd & Generation off grid & $5 \mathrm{MW}$ & Gas & NBL, & Lagos \\
\hline 28. & Tower Power Utilities ltd & Generation off grid & $20 \mathrm{MW}$ & Gas & Ota & Ogun \\
\hline
\end{tabular}

Source: Sambo, 2008.

Table 4: Types of Plant Biomass

\begin{tabular}{|c|c|c|c|}
\hline Woody Biomass & Non - Woody Biomass & Processed Waste & Processed Fuels \\
\hline Trees & $\begin{array}{l}\text { Energy crops such as } \\
\text { sugar cane }\end{array}$ & Cereal husks and cobs & $\begin{array}{l}\text { Charcoal (wood and } \\
\text { residues) }\end{array}$ \\
\hline Shrubs and Scrub & Cereal straw & Bagasse & $\begin{array}{l}\text { Briquetted or densified } \\
\text { biomass }\end{array}$ \\
\hline $\begin{array}{l}\text { Bushes such as coffee } \\
\text { and tea }\end{array}$ & $\begin{array}{l}\text { Cotton, cassava, tobacco } \\
\text { stems and roots (partly } \\
\text { woody) }\end{array}$ & $\begin{array}{l}\text { Wastes from pineapple } \\
\text { and other fruits }\end{array}$ & $\begin{array}{l}\text { Methanol and ethanol } \\
\text { (wood alcohol) }\end{array}$ \\
\hline $\begin{array}{l}\text { Sweeping from forest } \\
\text { floor }\end{array}$ & Grass & Palm oil cakes & $\begin{array}{l}\text { Plant oils such as palm, } \\
\text { rapeseed (canola) and } \\
\text { sunflower }\end{array}$ \\
\hline Bamboo & Bananas and Plantains & Sawmill waste & Producer gas \\
\hline \multirow[t]{3}{*}{ Palms } & $\begin{array}{l}\text { Soft stems, such as those } \\
\text { of pulses and potatos }\end{array}$ & $\begin{array}{l}\text { Industrial wood bark and } \\
\text { logging wastes }\end{array}$ & Biogas \\
\hline & Swamps and water plants & $\begin{array}{l}\text { Black liquor from pulp } \\
\text { mills }\end{array}$ & \\
\hline & & Municipal wastes & \\
\hline
\end{tabular}

The biomass resources of Nigeria consist of wood, forage grasses and scrubs, animal wastes arising from forestry, agricultural, municipal and industrial activities, as well as aquatic biomass. Previously, biomass dominated Nigeria's energy landscape, contributing 37\% of total energy demand, and the energy of choice for the vast majority of rural dwellers and the urban poor. The biomass energy resources of Nigeria have been estimated to be 144 million tonnes/year. Nigeria presently consumes about $43.4 \times 10^{9} \mathrm{~kg}$ of firewood annually. The average daily consumption is about 0.5 to $1.0 \mathrm{~kg}$ of dry wood per person. Table 5 shows the total area of Nigeria, distributed among the various uses.

Table 5: Nigeria's Size and land use parameters

\begin{tabular}{|l|c|c|}
\hline \multicolumn{1}{|c|}{ NIGERIA } & QUANTITY (Million ha) & PERCENTAGE \% \\
\hline A. SIZE & & 100 \\
\hline Land Area & 92.4 & 85.9 \\
\hline Water bodies (rivers, lakes etc) & 79.4 & 14.1 \\
\hline B. LAND USE & 13 & \\
\hline Agricultural Land & & 77.8 \\
\hline Arable Cropland & 71.9 & 30.5 \\
\hline Permanent Cropland & 28.2 & 2.7 \\
\hline Pasture Land & 2.5 & 30.6 \\
\hline Forest and Woodland & 28.3 & 11.6 \\
\hline Fadama & 10.9 & 2.2 \\
\hline Others & 2 & 8.1 \\
\hline
\end{tabular}

Source: Federal Ministry of Agriculture 
From the Table 5 it can be seen that of the total land area of 92.4 million hectares, 79.4 million is occupied by land while the remaining 13.0million hectares are occupied by water bodies. With regards to land use pattern the table also shows that agricultural lands occupy 71.9 million hectare, which are demarcated as shown in the table. Based on 2003 recorded crop production for Nigeria, there was an aggregate crop production of about 93.3 million tonnes for the major crops. This quantity refers to the harvested useful parts of the plants. This discarded parts consisting of roots, leaves, stalks, straws, chaff and other parts of plant shoot (otherwise called crop biomass) would be far in excess of this figure (REMP, 2005).

Table 6 further underscores Nigeria's potential for the production of manure, which is a key component of agricultural biomass. From the table it can be seen that Nigeria's livestock manure aggregated production of 285.1 million tonnes is potentially able to produce far more than 3 billion cubic meters of biogas yearly, which is more than 1.25 million tonnes of fuel oil per annum.

Table 6: Calculated manure production of Nigeria's livestock

\begin{tabular}{|l|l|c|c|c|c|c|c|}
\hline & \multicolumn{3}{|c|}{ ENGLAND } & \multicolumn{3}{c|}{ NIGERIA } & $\begin{array}{c}\text { Manure } \\
\text { Produced }\end{array}$ \\
\hline & Livestock & $\begin{array}{c}\text { Populatio } \\
\text { n } \\
\text { (millions) }\end{array}$ & $\begin{array}{c}\text { Manure } \\
\text { Produced } \\
\text { (Million } \\
\text { tonnes) }\end{array}$ & $\begin{array}{c}\text { FMA } \\
\text { (1997) } \\
\text { Population } \\
\text { (Millions) }\end{array}$ & $\begin{array}{c}\text { Manure } \\
\text { Produced } \\
\text { (Cal. figures) } \\
\text { (Million tonnes) }\end{array}$ & $\begin{array}{c}\text { Population } \\
\text { Based on } \\
\text { FMA } \\
\text { (1997) } \\
\text { Figures } \\
\text { (millions) }\end{array}$ & $\begin{array}{c}2001 \\
\text { (calculated } \\
\text { figures) } \\
\text { (million } \\
\text { tonnes) }\end{array}$ \\
\hline 1. & Cattle & 85 & 80 & 18.1 & 170.4 & 21 & 197.6 \\
\hline 2. & Sheep & 28 & 11 & 33.2 & 13 & 38.5 & 15.1 \\
\hline 3. & Goat & & & 53.8 & 21.1 & 62.4 & 24.5 \\
\hline 4. & Pig & 69 & 11 & 8.3 & 13.2 & 9.6 & 15.3 \\
\hline 5. & Poultry & 104 & 30 & 97.3 & 28.1 & 112.9 & 32.6 \\
\hline & Total & & $\mathbf{1 3 2}$ & & $\mathbf{2 4 5 . 9}$ & & $\mathbf{2 8 5 . 1}$ \\
\hline
\end{tabular}

Estimates made in 1985 give the number of cattle, sheep, goats, horses and pigs as well as poultry birds as 166 million. These produce 227,500 tonnes of animal wastes daily which come to $2.2 \mathrm{x} 109 \mathrm{MJ}$ taking the calorific value of animal dung to be $9,800 \mathrm{MJ} /$ tonne. Animal residue can be converted to biogas and estimates show that this is of the order of $5.36 \times 109 \mathrm{~m} 3$ which has an energy content amounting to $2.93 \times 109 \mathrm{kWh}$.(Sambo, 2005)

The foregoing shows that Nigeria has a huge and enormous potential for production of agricultural biomass. Other possible biomass resource base includes aquatic plants such as water hyacinth and municipal wastes both of which constitute major environmental problems. These present opportunities for meeting energy needs sustainably.

However, the resource base is under pressure from both human activities and natural factors such as drought. The major human activity that threatens the country's biomass resource base is the use of wood for cooking in the rural areas. This is because for most Nigerians, cooking is the most important energy need. Sixtyseven per cent of the population uses wood or charcoal as a cooking fuel. Wood fuel cooking is inefficient and is believed to be responsible for about 79,000 deaths annually from indoor air pollution (WHO, 2007). Kerosene is also used for cooking, but is polluting, hazardous and expensive; hence people also tend to prefer the taste (and experience) of food cooked on a fuel wood stove. In urban areas, the cost of fuel wood is increasing and in rural areas, fuel wood gathering takes 3-6 hours per day.

Also Wood, apart from being a major source of energy in the form of fuelwood is also used for commercial purposes in various forms as plywood, sawn wood, paper products and electric poles. For energy purposes, Nigeria is using 80 million cubic meters $(43.4 \times 109 \mathrm{~kg}$ ) of fuelwood annually for cooking and other domestic purposes. The energy content of fuelwood that is being used is $6.0 \times 109 \mathrm{MJ}$ out of which only between $5-12 \%$ is the fraction that is gainfully utilized for cooking and other domestic uses (Sambo, 2005).

Unsustainable use of fuel wood also contributes to deforestation. Unsustainable fuel wood gathering has put Nigeria's forests under pressure, particularly in the north. This has led to desertification, drought, arid land and a decline in crop production. These combine with the regional effects of climate change: a drop in the water table and a decline in rainfall. According to the Food and Agriculture Organization of the United Nation's State of the World's Forests report (FAO 2005), between 1990 and 2005, Nigeria lost 35.7 per cent of its forest cover.

Although the biomass availability as at 1973 was put at $9.1 \times 1012 \mathrm{MJ}$, it is expected that the overall biomass resource availability at present is lower than the 1973 figure. This is largely due to the demand of wood also for construction and furniture industries in addition to its use as an energy source. As for forage grasses and shrubs, estimates show that 200 million tonnes of dry biomass can be obtained from them and this comes up to $2.28 \mathrm{x}$ $106 \mathrm{MJ}$ of energy. For crop residues and wastes, estimates of the 6.1 million tonnes of dry biomass that are produced annually leave residues whose energy content approximate to 5.3 x $1011 \mathrm{MJ}$. 


\subsection{Renewables}

Renewable energy and technologies have great potential to provide solutions to the long - standing energy problems being faced by the developing countries including Nigeria. In promoting the diffusion of renewable energy into the country's energy supply mix for sustainable development, the government approved in November 2005, the Renewable Energy Master plan (REMP). The REMP was prepared by the Energy Commission of Nigeria (ECN) in collaboration with the United Nations Development Programme (UNDP).

The overall objective of the Renewable Energy Master Plan (REMP) is to articulate a national vision, targets and a road map for addressing key energy development challenges facing Nigeria through the accelerated development and exploitation of renewable energy. It will put in place a comprehensive framework for developing renewable energy policies, legal instruments, technologies, manpower, infrastructure and market to ensure that the visions and targets are realized.

The master plan sets clear and verifiable national targets in the short, medium and long term. Short term targets will be achieved by the year 2007, medium term targets will be achieved by the year 2015 coinciding with the target year for the MDGs; long term targets are set for 2025, two decades after launching of the REMP.

As a further boost to developing renewable energy technology in Nigeria, in 2007, the federal Executive Council approved a biofuels policy framework for the NNPC - Nigerian National petroleum Corporation. The Nigerian government is also piloting large-scale biofuels production for use in automobiles and generators, and for bio-gas production. The NNPC also received a grant of 70,000 Euros from the Renewable Energy and Energy Efficiency Partnership (REEEP) to support a detailed feasibility study into high ethanol-yielding cassava varieties and other biofuels feedstock for production of two types of automotive fuel: ethanol fuel and palm oil diesel (Shaad et al, 2009)

The government has also signed an MOU with Brazil for technology transfer and supply of ethanol from sugar cane, including importing ethanol from Brazil until Nigeria is ready to start producing. There is a further agreement with Cuba on ethanol supply. Ethanol will be used as an additive to petrol, constituting a proposed 10 per cent of the mix.

Also, as part of government plans to increase power generation through the incorporation of renewable energy resources; the following projects are expected to be executed in the NV20:2020 first medium implementation plan.

1. Construction of a 10MW Katsina wind project. The project was awarded in 2010 and is the first wind farm project in the country and is scheduled to be completed in 2011. At completion, the wind farm is expected to supplement electricity supply to communities in Katsina and serve as pilot project for wind technology development for potential private sector investors.

2. Construction of 2600MW Mambilla Hydroelectric Power Project (HEPP). This is a major renewable energy project that is critical to the realization of the energy supply security beyond 2013. The project is expected to have a generation capacity of 2600MW base load electricity power and will be implemented over a 5 year period. The project is also expected to deliver $330 \mathrm{Km}$ of $720 \mathrm{KV}$ transmission line to Jalingo and $330 \mathrm{~km}$ from Abong to Markurdi.

3. Construction of 700MW Zungeru Hydropower Project. The project is expected to deliver an optimal capacity of $525 \mathrm{MW}$, with future expansion to $700 \mathrm{MW}$. As part of efforts to complete the project on schedule, in 2010, a contract was awarded for the preparation of the tender documents, while the process for procuring a consultant for the environmental Impact Assessment (EIA) for the project is ongoing.

4. In order to facilitate off - grid electricity extension to the rural and remote areas, various solar rural electrification projects were awarded in 2010 in various communities in Cross - River states, Ogun State, Bauchi State and Katsina State. The projects are expected to be completed within the plan period.

5. Small and medium Hydro Electric Power Plants (HEPP) is also expected to be constructed as part of the long term plans for power security. In the current power plan, the FGN is preparing the term of reference for the development of small and medium scale HEPP through the Ministry of Power in collaboration with the Nigerian Infrastructure Advisory Facility (NIAF). The project will include the construction of Turbines with all the associated equipments on existing dams to generate electricity. The specific projects locations will be determined after the preliminary studies.

\section{Challenges and Prospects of the Energy sector in Nigeria}

From the foregoing, it is clear that the Nigerian energy sector is confronted by a lot of challenges, which were created due to inadequate planning, implementation and expansion of the sector to meet a growing demand base, which was created primarily by an appreciable increase in population over the past twenty years. Some of the identified challenges include: Despite the installed petroleum products refining capacity of 445,000 barrel/day and electricity generation capacity in excess of 8,000 MW, Nigeria imports over $70 \%$ of its petroleum products requirement, while electricity supply is inadequate at just about 3,000 MW now. The rate at which new 
power plants and new oil refineries together with associated infrastructure are added to into the system is very low.

Also, the new licensees of NERC have not made appreciable progress due to problems of bankability of proposals, agreements on power purchase and securitization. Coal and Renewable energy resources are grossly underutilized in the country despite their availability in reasonable quantities. Natural gas supply is grossly inadequate for the existing gas power plants

For the country to attain sustainable energy to meet the needs of the residential, commercial and industrial sector of the nation, the following steps must be taken urgently:

1. There is an urgent need for the ongoing reforms in the oil \& gas and power sector to be pursued with renewed vigour and seriousness.

2. Existing underutilized energy infrastructure in the country should be upgraded to operate at optimum conditions.

3. New energy infrastructures should be put in place at a faster rate .

4. The energy mix into the economy should be diversified to include Nuclear, Coal, Solar, Wind and biofuels.

\section{References}

[1]. Adenikinju, A (2008) Efficiency of the Energy sector and its impact on the competitiveness of the Nigerian economy. Paper presented at the first international conference of the International Association of Energy Economics.

[2]. Akarakiri, J.B(1999). Private electric power generation as an alternative in Nigeria. Energy 24 (5), pg $445-457$.

[3]. Bureau of Public Enterprises (BPE, 2011). "Power Generation (Status and Outlook)". Paper Presented at the Nigeria Power Sector Investment Forum in London, 27 January, available at http://www.bpeng.org/Electric Power/Pages/

[4]. Energy Commission of Nigeria (2005); Renewable Energy Master Plan, November.

[5]. EL - Rufai, N.A (2001) Attracting private sector investment in the Power sector. The perspective of the Nigerian government reform agency. Paper presented at the Bureau of Public Enterprises, $1^{\text {st }}$ November.

[6]. Energy Information Administration (EIA,2011); Nigerian Energy Profile, available atwww.eia.gov/Nigeria.

[7]. FAO (Food and Agriculture Organization of the United Nations) (2005), State of the World's Forests, United Nations Food and Agriculture Organization, Rome. Available at ww.fao.org/docrep/007/y5574e/y5574e00.htm) Ige, D (2011) "Gas to Power-Status and Outlook" given at the Nigeria Power SectorInvestment Forum in London, $27^{\text {th }}$ January.

[8]. Labo, H.S. (2010) Current status and future outlook of the transmission network. Paper Presented at the investor;s forum for the privatization of the PHCN successor company,January $18-19^{\text {th }}$.

[9]. Malik, A., F. Teal and S. Baptist (2004) The Performance of Nigerian Manufacturing Firms: Report on the Nigerian Manufacturing Enterprise Survey, United Nations Industrial Development Organization, Nigerian Federal Ministry of Industry and Centre for the Study of African Economies, Department of Economics, University of Oxford. (www.gprg.org/pubs/reports/pdfs/2006-04-malik-tealbaptist.pdf)

[10]. Maigida, S. (2008), 'Power Sector Infrastructural Development by 2020: Issues and Challenges". Paper Presented at the 1st International Conference of NAEE/IAEE at the Transcorp Hilton Hotel, 29th - 30th of April

[11]. Sambo, A. S. (1997): "Energy options for sustainable national development: Resources, issues, and the position of renewable energy technologies", University Inaugural Lecturedelivered on 17th January, 1996, Published as Inaugural Lecture Series No. 1, ATBU

[12]. Sambo, A,S (2009) The challenge of Sustainable Energy development in Nigeria: Paper presented to the Nigerian Society of Engineers Forum, Abuja, $2^{\text {nd }}$ April.

[13]. Shaad, B and Wilson, E (2009) Access to sustainable energy: What role for international oil and gas companies? Focus on Nigeria. Published by International Institute for Environment and Development (IIED) available on www.iied.org/pubs; 